\title{
REFERENCES
}

Bloch, K., Berg, B. N. \& Rittenberg, D. (1943). J. biol. Chem. $149,511$.

Cook, R. P. (1937). Biochem. J. 31, 410.

Cook, R. P. (1938). Biochem. J. 32, 1191.

Cook, R. P. (1942). Nutr. Abstr. Rev. 12, 1.

Hilditch, T. P. (1940). The Chemical Constitution of Natural Fats, lst ed. London: Chapman and Hall.
Little, H. N. \& Bloch, K. (1950). J. biol. Chem. 183, 33.

McCollum, E. V. \& Davis, M. (1915). J. biol. Chem. 20, 641.

Polgar, N. (1948). Biochem. J. 42, 206.

Rosenheim, O. \& Webster, T. A. (1941). Biochem. J. 35, 920.

Schoenheimer, R. \& Sperry, W. M. (1934). J.biol. Chem. 106, 745.

Turfitt, G. E. (1948). Biochem. J. 42, 376.

\section{Manometric Determination of L-Aspartic Acid and L-Asparagine}

\author{
By H. A. KREBS \\ Medical Research Council Unit for Research in Cell Metabolism, \\ Department of Biochemistry, University of Sheffield
}

(Received 8 June 1950)

Gale (1945) has developed specific and accurate methods employing bacterial decarboxylases by which six amino-acids-glutamic acid, ornithine, arginine, lysine, histidine and tyrosine-can be determined in quantities from $0.05 \mathrm{mg}$. upwards. The method for the determination of L-aspartic acid described in this paper supplements Gale's methods. It is based on the combined use of aspartic-glutamic transaminase and of the glutamic and oxaloacetic decarboxylases. In a system containing these three enzymes, as well as L-aspartic acid and an excess of $\alpha$-ketoglutarate, the following three reactions take place:

(1) L-Aspartic acid $+\alpha$-ketoglutaric acid $\stackrel{\text { aspartic-glutamic transaminase }}{\longrightarrow}$

L-glutamic acid + oxaloacetic acid,

(2) Oxaloacetic acid oxaloacetic decarboxylase

(3) L-Glutamic acid

glutamic decarboxylase $\gamma$-aminobutyric acid $+\mathrm{CO}_{2}$.

The overall effect of these three reactions is:

(4) L-Aspartic acid $+\alpha$-ketoglutaric acid $=\gamma$-aminobutryic acid + pyruvic acid $+2 \mathrm{CO}_{2}$.

As the products of reaction 1 are removed quantitatively by the reactions 2 and 3 the reversible reaction 1 proceeds quantitatively from left to right and two molecules of carbon dioxide are formed for each molecule of aspartic acid present. This principle can also be used for the determination of $\alpha$-ketoglutaric acid. If an excess of aspartic acid is added to the system containing the three enzymes and an unknown quantity of $\alpha$-ketoglutaric acid, the latter limits the extent of the reactions 1, 2 and 3, and two molecules of carbon dioxide are formed for each molecule of $\alpha$-ketoglutaric acid.

L-Asparagine can be determined by this principle if the enzymes catalysing 1,2 and 3 are supplemented by asparaginase which hydrolyses Lasparagine:

$$
\text { Asparagine }=\text { aspartic acid }+\mathrm{NH}_{3} \text {. }
$$

If glutamic decarboxylase is omitted from the above series of catalysts, one molecule of carbon dioxide is formed for each molecule of aspartic acid or $\alpha$-ketoglutaric acid, the balance of reactions 1 and 2 being:

L-Aspartic acid $+\alpha$-ketoglutaric acid $=$ glutamic acid + pyruvic acid $+\mathrm{CO}_{2}$.

Thus a combination of transaminase, oxaloacetic decarboxylase and asparaginase may also be used for the manometric determination of aspartic acid, asparagine or $\alpha$-ketoglutaric acid. The omission of glutamic decarboxylase halves the sensitivity of the method, but this simplified procedure may be more convenient when facilities for preparing glutamic decarboxylase are limited. The only special reagent required for the simplified procedure is a transaminase preparation which is easily obtainable.

\section{METHODS}

The first part of the paper is concerned with the study of the four catalysts required for the methods. Clostridium welchii, strain SR 12, served as a source of glutamic decarboxylase, heart muscle as a source of aspartic-glutamic transaminase, aniline as a catalyst for the decarboxylation of oxaloacetate and guinea pig serum or liver as a source of asparaginase.

\section{Preparation of suspensions of Clostridium welchii}

The medium used for sub-culture and for preparing inocula is essentially the 'Cooked Meat Medium' described by Lepper \& Martin (1929). The medium for growing bulk supplies 
combines the ingredients of the medium of Lepper \& Martin with those of Gale's (1947) medium (glucose-casein hydrolysate) and contains in addition yeast extract and phosphate buffer. Various modifications which have been tested, in particular the omission of the washed ox-heart mince, reduce the yield of the organism or the activity of the glutamic decarboxylase. With the medium used the yield of the decarboxylase for the same volume of medium is about three times greater than that given by Gale. Moreover, the stability of the enzyme seems to be greater so that washed suspension can be kept for many weeks. It is a further advantage that anaerobic conditions are not required for growth or for the preservation of the washed suspension. Pyruvic acid is not decarboxylated by the organism (strain SR 12) if the latter is grown and treated as described in this paper (see Boulanger \& Osteux, 1949).

\section{Stock solutions}

Acid casein hydrolysate with phosphate. This is prepared according to McIlwain \& Hughes (1944) except that no oxalic acid is used for the precipitation of $\mathrm{Ca}$ as this was found unnecessary. The medium is stored with $\mathrm{CHCl}_{3}$ in the refrigerator in the form of the 'basal medium' described by these authors. It may be replaced by commercially available enzymic casein digests (e.g. 'Pronutrin', Herts. Pharmaceuticals Ltd., Welwyn Garden City) and phosphate buffer.

$Y$ east extract. Fresh baker's yeast $(450 \mathrm{~g}$.) is crumbled into $500 \mathrm{ml}$. of boiling water and kept simmering for $15 \mathrm{~min}$. The suspension is filtered through 'New Agar-Agar Paper' no. $904 \frac{1}{2}$ (J. Barcham Green Ltd., Maidstone, England); the filtrate is stored over $\mathrm{CHCl}_{3}$.

Peptone infusion broth. Fresh ox heart, freed from fat, is minced in a kitchen mincer, using the plate with the smallest perforations. The mince (500 g.), peptone ('Oxo' or 'Bacto') ( 10 g.) and $\mathrm{NaCl}(5 \mathrm{~g}$.) are placed in $500 \mathrm{ml}$. of boiling water and simmered for $20 \mathrm{~min}$. The liquid is strained off through muslin, filtered through Green's agar filter and treated with $\mathrm{N}-\mathrm{NaOH}$ until it is blue to thymol blue. It is then heated to about $90^{\circ}$ until a precipitate of calcium phosphate has formed and filtered hot. After adjustment of $\mathrm{pH}$ to $\mathbf{7 . 6}$ with $\mathrm{N}-\mathrm{HCl}$ the broth is stored over $\mathrm{CHCl}_{3}$.

Washed ox-heart mince. The mince left over from the preparation of the infusion broth is used. It is squeezed as dry as possible through muslin and then spread on filter paper and left overnight. For storage $80 \mathrm{~g}$. lots of mince are mixed with $50 \mathrm{ml}$. of peptone infusion broth and $50 \mathrm{ml}$. of water in $250 \mathrm{ml}$. conical flasks and autoclaved.

Glucose. The stock solution contains $20 \mathrm{~g}$. glucose and 1 drop of syrupy $\mathrm{H}_{3} \mathrm{PO}_{4} / 100 \mathrm{ml}$. It is sterilized by autoclaving.

\section{Sub-cultures for maintenance and inoculation}

An approx. $3 \mathrm{~cm}$. layer of washed heart mince is put into each test tube, followed by $3 \mathrm{ml}$. of water and $3 \mathrm{ml}$. of peptone infusion broth. The tubes are placed in boiling water for $30 \mathrm{~min}$. before they are autoclaved to remove air.

\section{Preparation of bulk supplies of bacterial suspensions}

Acid casein hydrolysate $(80 \mathrm{ml}$.) and $560 \mathrm{ml}$. of water (or alternatively $20 \mathrm{~g}$. of 'Pronutrin' and $560 \mathrm{ml}$. of $0.05 \mathrm{M}$ phosphate buffer pH 7.6) together with one $80 \mathrm{~g}$. lot of washed ox heart and $100 \mathrm{ml}$. of infusion broth are sterilized by autoclaving in a 1 l. conical flask. After cooling, $50 \mathrm{ml}$. of sterile glucose solution are added. This medium is inoculated by adding the contents of a $24 \mathrm{hr}$. test tube culture to the medium. The flask is kept for $16 \mathrm{hr}$. at $37^{\circ}$ in air. If growth is satisfactory, the $\mathrm{pH}$ at the end of the incubation has fallen to $4 \cdot 0-4 \cdot 5$. At the completion of the incubation the medium is shaken up and the supernatant is strained through glass wool. The heart residue is washed twice with $50 \mathrm{ml}$. of $0.9 \% \mathrm{NaCl}$ solution. The final yield of the sediment is usually 4-5 g. wet weight. For each g. wet weight $10 \mathrm{ml}$. of $0 \cdot 2 \mathrm{M}$-acetate buffer pH 4.5 are added. The suspension obtained is stored in the refrigerator where its activity remains fairly constant for 1 or 2 months. Under standard conditions $0.5 \mathrm{ml}$. of this suspension decarboxylates $10^{-5} \mathrm{~mol}$. glutamic acid $(224 \mu \mathrm{l}$.) quantitatively in 10-20 min. This suspension, if added to

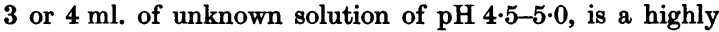
specific reagent for L-glutamic acid. The only other substances known to cause a production of $\mathrm{CO}_{2}$ are oxaloacetic and acetoacetic acids. Both may be decomposed prior to the addition of the bacterial suspension by pipetting $0.05 \mathrm{ml}$. of aniline into the main compartment of the manometer vessel.

\section{Inhibition of glutamic decarboxylase}

When the bacterial enzyme is used in complex media it has to be ascertained whether the medium contains substances which inactivate the enzyme. Taylor \& Gale (1945) have

Table 1. Effect of various substances on the activity of glutamic decarboxylase of washed suspension of $\mathrm{Cl}$. welchii

(The substances tested were placed, together with acetate buffer $\mathrm{pH} 5 \cdot 0,0.04 \mathrm{M}$ final concentration, and the bacterial suspension in the main compartment of the manometer vessel; L-glutamate dissolved in acetate buffer was in the side arm. In all cases except those marked *, the final yield of $\mathrm{CO}_{2}$ was not affected by the added substance.)

Substance added $\quad \begin{array}{cc}\text { Concentration } & \begin{array}{c}\text { Inhibition of } \\ \text { initial rate }\end{array} \\ (\mathbf{M}) & (\%)\end{array}$

Neutral salts

$\begin{array}{llc}\mathrm{NaCl} & 0 \cdot 7 & 60 \\ \mathrm{Na}_{2} \mathrm{SO}_{4} & 0 \cdot 33 & 15 \\ \text { Sodium acetate-acetic acid } & 0 \cdot 7 & 75 \\ \mathrm{KCl} & 1 \cdot 4 & 78 \\ \mathrm{CaCl}_{2} & 0 \cdot 1 & 50 \\ \mathrm{FeCl}_{3} & 0 \cdot 013 & 99 * \\ \mathrm{CoCl}_{2} & 0 \cdot 05 & 0 \\ \mathrm{CdCl}_{2} & 0 \cdot 015 & 60 \\ \mathrm{AlCl}_{3} & 0 \cdot 027 & 25 \\ \mathrm{MnCl}_{2} & 0.020 & 12\end{array}$

Deproteinizing agents (neutralized)

Sodium metaphosphate $\quad 0 \cdot 18$

Sodium tungstate $\quad 0.027$

$\mathrm{NaClO}_{4} \quad 0.18$

Sodium trichloroacetate $\quad 0.10$

25

97*

75

40

Heavy metal reagents

$\begin{array}{lll}\mathrm{Na}_{2} \mathrm{~S} & 0.022 & 30 \\ \mathrm{NaN}_{3} & 0.022 & 15 \\ \text { 8-Hydroxyquinoline } & 0.022 & 10 \\ 4: 4^{\prime} \text {-Dipyridyl } & 0.022 & 15\end{array}$

Aldehyde reagents

Hydroxylamine

Hydroxylamine

Phenylhydrazine

$\mathrm{Na}_{2} \mathrm{SO}_{3}$

Semicarbazide

HCN

$\begin{array}{ll}5 \times 10^{-5} & 88^{*} \\ 5 \times 10^{-4} & 99^{*} \\ 0.005 & 75 \\ 0 \cdot 022 & 65 \\ 0.022 & 50 \\ 10^{-4} & 95^{*}\end{array}$


shown that some heavy metals ( $\mathrm{Ag}, \mathrm{Hg}$ and $\mathrm{Cu}$ ), $\mathrm{HCN}$ and some aldehyde reagents $\left(\mathrm{NH}_{2} \mathrm{OH}\right)$ inhibit the enzyme. Further data of interest in connexion with the analytical use of the enzyme are shown in Table 1. No serious interference in the activity of the enzyme was found when deproteinizing agents, after neutralization to $\mathrm{pH} 5 \cdot 0$, or fairly high concentrations of neutral salts $\left(\mathrm{NaCl}, \mathrm{Na}_{2} \mathrm{SO}_{4}\right)$ were added. Such salts may be present in the solution to be tested when the original solution is strongly acid, or so dilute that it has to be concentrated. Some of the substances tested reduced the rate of the decarboxylation, but so long as the inhibition did not exceed $80 \%$, the final yield of $\mathrm{CO}_{2}$ was not affected by the inhibitor. Narcotics (saturated caprylic alcohol, $\mathrm{CHCl}_{3}$, toluene, phenylurethane) had no effect.

Under the conditions of the test the inhibitor was in contact with the bacteria for at least $20 \mathrm{~min}$. at $40^{\circ}$ (i.e. during the equilibration period) before the glutamate was added. The experiments were repeated with the bacterial suspension in the side arm and glutamic acid and inhibitor in the main compartment. The degree of inhibition was the same except with tungstate and $\mathrm{FeCl}_{3}$ when it was smaller $(30 \%$ with both).

\section{Transaminase preparation}

To obtain manometrically a quantitative yield of $\mathrm{CO}_{2}$ from glutamic acid and oxaloacetic acid, the $\mathrm{pH}$ of the medium must not be higher than 5.0 because of the retention of $\mathrm{CO}_{2}$ in less acid solutions. The optimal $\mathrm{pH}$ of heart transaminase is 7.6 (Cohen, 1940), and at pH 5.0 only a small fraction of the optimal activity remains. As it is a requirement of quantitative decarboxylation according to reactions 1,2 and 3 that transaminase and decarboxylases should act upon the substrate at the same time a very powerful transaminase preparation is needed for the method. Purity of the enzyme is not necessary, owing to the high specificity of the enzymes, but aspartic acid and its precursors (e.g. protein plus proteolytic enzymes) must be absent.

Assay of transaminase activity. The rate of $\mathrm{CO}_{2}$ evolution from reaction 4 was found under suitable conditions (i.e. at low transaminase and high decarboxylase activity) to be proportional to the concentration of transaminase and the measurement of the rate can therefore be used for the assay of the enzyme. This assay method has the advantage over others (see Green, Leloir \& Nocito, 1945) that a number of readings are obtained for each enzyme concentration.

A study of the properties of transaminase and the other enzymes involved in the test (see later) led to the adoption of the following conditions: the main compartment of the manometer vessel contained the transaminase preparation with $0.5 \mathrm{ml}$. of $0.2 \mathrm{M}$-acetate buffer $\mathrm{pH} 5 \cdot 0,0.5 \mathrm{ml}$. of horse or ox serum, $0.1 \mathrm{ml}$. of $2 \%$ cetavlon, $0.1 \mathrm{ml}$. of $0.2 \mathrm{M}-\mathrm{DL}$ aspartate, $0.5 \mathrm{ml}$. of suspension of $\mathrm{Cl}$. welchii and water to $4.0 \mathrm{ml}$. The side arm contained $0.2 \mathrm{ml}$. of $0.2 \mathrm{M}$-acetate buffer $\mathrm{pH} 5 \cdot 0,0.1 \mathrm{ml}$. of $0.2 \mathrm{M}-\alpha$-ketoglutarate and $0.05 \mathrm{ml}$. of aniline. The gas space was filled with $\mathrm{N}_{2}$; temp. $40^{\circ}$. A dilute extract from ethanol-dried horse heart, containing $0.7 \mathrm{mg}$. dry matter/ml., gave the following rates of $\mathrm{CO}_{2}$ evolution:

$\begin{array}{cc}\begin{array}{c}\text { Transaminase } \\ \text { solution } \\ (\mathrm{ml} .)\end{array} & \begin{array}{c}\mathrm{CO}_{2} \text { evolved } \\ \text { in l hr. } \\ (\mu \mathrm{l} .)\end{array} \\ 0 \cdot 1 & 16 \\ 0 \cdot 2 & 32 \\ 0 \cdot 4 & 58 \\ 0 \cdot 8 & 101 \\ 1 \cdot 6 & 164\end{array}$

This procedure proved satisfactory for testing the relative activities of transaminase preparations. Similar results were obtained when glutamic decarboxylase was omitted except that the rate of $\mathrm{CO}_{2}$ evolution was halved.

Fresh heart-muscle extract. For many purposes horse or sheep heart extracts, prepared by mixing 2 parts of $0.5 \%$ $\mathrm{NaCl}$ solution with 1 part of finely minced heart muscle and centrifuging, have proved satisfactory. Preserved with a drop of octanol these extracts, if kept in a refrigerator, maintained their activity for several weeks. The heart should be removed from the animal within a few minutes after death and cooled or frozen until it can be minced.

Dry heart-muscle preparation. Cardiac muscle of horse or sheep was homogenized in a Waring blender with 3 vol. of water. The homogenate was centrifuged, the insoluble part discarded and the supernatant, which contained about $70 \%$ of the transaminase activity and $45 \%$ of the dry matter of the tissue, was reduced in vacuo to about one-tenth of the original volume at a bath temperature of about $40^{\circ}$. An effective metal condenser and a distilling flask provided with a dropping funnel or other device allowing the continuous addition of fluid were required. The concentrate was dialysed against running tap water for $6 \mathrm{hr}$.; this removed about $60 \%$ of the dry matter. The dialysed material was dried in a vacuum desiccator over $\mathrm{P}_{2} \mathrm{O}_{5}$. During these operations the loss of enzyme activity was small. The dry residue was ground to a powder and stored in a desiccator where the transaminase activity remained fairly constant for several months. From $570 \mathrm{~g}$. of fresh heart muscle $25 \mathrm{~g}$. of dried 'transaminase' were obtained. For use a $10 \%$ solution in $0.5 \% \mathrm{NaCl}$ was made.

Highly purified preparations. Purified transaminase can be prepared without difficulty (O'Kane \& Gunsalus, 1947), but purification is as a rule not required since impurities, owing to the specificity of the enzymes, do not interfere.

Specificity. No other amino-acid has been found to transaminate under the test conditions with $\alpha$-ketoglutarate except L-cysteic acid (Bychov, 1939; Cohen, 1940). Alanine and phenylalanine, which react under certain conditions (alanine at $\mathrm{pH} \mathbf{7 . 4}$ with heart-muscle preparations, phenylalanine at the same $\mathrm{pH}$ with liver preparations), do not measurably interfere. $\alpha$-Aminoadipic acid is neither decarboxylated by $\mathrm{Cl}$. welchii nor does it transaminate with $\alpha$-ketoglutarate at $\mathrm{pH} \mathrm{5.0.}$

L-Cysteic acid reacts in the test at about the same rate as L-aspartic acid if present in high concentrations (above $0.02 \mathrm{M}$ ). At lower concentrations the rate falls, as the affinity of cysteic acid for the enzyme is rather low, the halfmaximum rate occurring at $2.5 \times 10^{-3} \mathrm{M}$. Cysteic acid, of course, yields only one equivalent of $\mathrm{CO}_{2}$ as the corresponding ketonic acid (sulphopyruvic acid), unlike oxaloacetic acid, does not undergo decarboxylation. It has not been possible to separate the catalysts responsible for the reactivity of cysteic acid and aspartic acid; they are probably identical.

As cysteic acid is not present in the materials commonly encountered, interference from this substance in the determination of aspartic acid will be exceptional.

An unusual type of interference with the specificity may arise if inhibitors of glutamic decarboxylase belonging to the group of 'aldehyde reagents' (see Table 1) are present. Any glutamic acid present in the unknown solution is in this case not decarboxylated during the equilibration period owing to the inhibition of glutamic decarboxylase. Addition of $\alpha$ ketoglutarate removes the aldehyde reagent and restores the activity of glutamic decarboxylase. An example is the 
following: a manometer vessel with two side arms contained $3 \mathrm{ml}$. of $0.04 \mathrm{~m}$-acetate buffer with $0.06 \%$ cetavlon, $2 \times 10^{-5} \mathrm{~mol}$. L-glutamic acid and $3 \times 10^{-3} \mathrm{M}-\mathrm{NH}_{2} \mathrm{OH}$. $\mathrm{HCl}$ in the main compartment. The first side arm contained $0.5 \mathrm{ml}$. of $\mathrm{Cl}$. welchii suspension, the second $0.4 \mathrm{ml}$. of $0.1 \mathrm{M}-\alpha-$ ketoglutarate in $0 \cdot 1 \mathrm{M}$-acetate buffer $\mathrm{pH} 5 \cdot 0$. Temperature, $40^{\circ}$; gas, $\mathrm{N}_{2}$. After equilibrium the bacterial suspension was mixed with the glutamate and no evolution of $\mathrm{CO}_{2}$ occurred in the following $30 \mathrm{~min}$. The contents of the second side arm were then tipped into the main compartment. The $\mathrm{CO}_{2}$ evolution was as follows: after $10 \mathrm{~min}$., $76 \mu \mathrm{l}$.; after $20 \mathrm{~min}$., $276 \mu \mathrm{l}$.; after $40 \mathrm{~min}$., $426 \mu \mathrm{l}$.; after $60 \mathrm{~min}$., $452 \mu \mathrm{l}$. (calc. for complete decarboxylation, $448 \mu \mathrm{l}$.). In a similar experiment in which $\mathrm{HCN}$ instead of $\mathrm{NH}_{2} \mathrm{OH}$ was the inhibitor of glutamic decarboxylase, the effect of $\alpha$-ketoglutarate on the inhibition was only slight.

Inhibition of transaminase. The following substances, when tested in the concentrations stated in Table 1, did not interfere with the use of transaminase: $\mathrm{NaCl}$, sodium acetate, sodium metaphosphate, sodium trichloroacetate, $\mathrm{CoCl}_{2}$, $\mathrm{CdCl}_{2}, \mathrm{MnCl}_{2}$. Although the initial rate of $\mathrm{CO}_{2}$ evolution was decreased in some cases the final yield of $\mathrm{CO}_{2}$ was not affected. $\mathrm{Na}_{2} \mathrm{SO}_{4}$ and other sulphates inhibited strongly in concentrations above 0.05 м (cf. also Braunstein, 1947).

\section{Decarboxylation of oxaloacetate}

Suspensions of $\mathrm{Cl}$. welchii and transaminase preparations decarboxylate oxaloacetate at $\mathrm{pH} 5 \cdot 0$. However, the reaction is not rapid compared with decarboxylation of glutamic acid, and whether it is non-enzymic or (partly) enzymic has not been investigated. The rate of $\mathrm{CO}_{2}$ evolution in the system bringing about reaction 4 is greatly accelerated by the addition of agents which decarboxylate oxaloacetate, such as aniline or multivalent cations, e.g. $\mathrm{CoCl}_{2}$ (Table 2). The amount of creases; the rate of loss of activity is lowered in the presence of serum or of other solutions containing protein. If transaminase is present and if the aniline $(0.05 \mathrm{ml}$.) is kept in the side arm during the equilibration period, the inhibitory effect of aniline on the glutamic decarboxylase is not serious.

\section{Asparaginase}

Asparaginase activity is found in many animal and plant tissues. It is also present in guinea pig blood serum, but absent from the serum of most other mammalian species (Lang, 1904; Fürth \& Friedmann, 1910; Clementi, 1922; Geddes \& Hunter, 1928). Its $\mathrm{pH}$ optimum is between $7 \cdot 1$ and 7.4 (Krebs, unpublished data; see also Clementi \& Prampolini, 1929; Suzuki, 1936; Hiwatasi, 1941) and in acetate buffer at $\mathrm{pH} 5.0$ the activity is about $20-30 \%$ of that in phosphate buffer at pH $\mathbf{7 \cdot 4}$. Therefore highly active preparations are required for the present purpose. Among the known sources of asparaginase, guinea pig liver and serum are the richest. The following preparations were used:

Guinea pig serum. This was regularly available through the courtesy of the Department of Bacteriology where animals had to be killed in the guinea pig inoculation test for the detection of tubercle bacilli. To $50 \mathrm{ml}$. serum $1 \mathrm{ml}$. of $\mathrm{N}-\mathrm{HCl}$ was added to adjust the $\mathrm{pH}$ to about 5 . If the serum is also added to a control test no steps need to be taken to remove the traces of aspartic acid and $\alpha$-ketoglutarate present in the serum. When preserved with a drop of sec.octanol and kept in the refrigerator the asparaginase activity of serum remained constant for several weeks.

A stable dry preparation of serum asparaginase was obtained by adding to ice-cold serum, whilst stirring vigorously, 2 vol. of ice-cold ethanol. After centrifugation the sediment was dried in a desiccator over $\mathrm{H}_{2} \mathrm{SO}_{4}$. From $10 \mathrm{ml}$. serum about $0 \cdot 5 \mathrm{~g}$. dry powder were obtained. About one-half of the

\section{Table 2. Effect of aniline and cobaltous chloride on the evolution of carbon dioxide in a system containing aspartic acid, $\alpha$-ketoglutaric acid, transaminase and glutaric decarboxylase}

(Main compartment in all cups: $0.2 \mathrm{ml}$. transaminase (10\% 'dry heart preparation'); $0.5 \mathrm{ml} . \mathrm{Cl}$. welchii; $0.1 \mathrm{ml} .2 \%$ cetavlon; $0.5 \mathrm{ml} .0 .2 \mathrm{M}$-acetate buffer, $\mathrm{pH} 5 \cdot 0 ; 0 \cdot 1 \mathrm{ml}$. $0.2 \mathrm{M}$-DL-aspartate; water to $4.5 \mathrm{ml}$. Side arm: $0 \cdot 1 \mathrm{ml}$. $0 \cdot 2 \mathrm{M}-\alpha-\mathrm{keto}$ glutarate; $0 \cdot 2 \mathrm{ml}$. $0 \cdot 2 \mathrm{M}$-acetate buffer, $\mathrm{pH} \mathrm{5 \cdot 0.)}$

\begin{tabular}{|c|c|c|c|c|c|}
\hline \multirow[b]{2}{*}{$\begin{array}{c}\text { Addition to side arm } \\
\text { Time (min.) }\end{array}$} & \multirow{2}{*}{$\ldots$} & \multicolumn{4}{|c|}{$\mathrm{CO}_{2}$ evolved after mixing $(\mu \mathrm{l})}$. \\
\hline & & $\begin{array}{c}1 \\
\mathrm{Nil}\end{array}$ & $\begin{array}{c}2 \\
\text { Aniline } \\
(0.05 \mathrm{ml} .)\end{array}$ & $\begin{array}{c}3 \\
\text { Aniline } \\
(0.025 \mathrm{ml} .)\end{array}$ & $\begin{array}{c}4 \\
\mathrm{M}-\mathrm{CoCl}_{2} \\
(0 \cdot 1 \mathrm{ml} .)\end{array}$ \\
\hline 5 & & 19 & 33 & 26 & 29 \\
\hline 10 & & 29 & 102 & 75 & 75 \\
\hline 20 & & 64 & 251 & 197 & 184 \\
\hline 35 & & 107 & 355 & 285 & 266 \\
\hline 45 & & 136 & 414 & 351 & 328 \\
\hline 60 & & 193 & 446 & 420 & 399 \\
\hline 80 & & 256 & 450 & 438 & 436 \\
\hline 110 & & 322 & 449 & 449 & 445 \\
\hline
\end{tabular}

$\mathrm{CO}_{2}$ evolved in the first $20 \mathrm{~min}$. is almost quadrupled by aniline. Increase in the rate of reaction alone could at the most double the rate of $\mathrm{CO}_{2}$ evolution and it may therefore be assumed that aniline also accelerates 1 by removing one of its reaction products. As aniline was the most effective catalyst it was adopted for the standard procedure. A difficulty arose from the inhibitory action of aniline on glutamic decarboxylase found under certain conditions. If a suspension of $\mathrm{Cl}$. welchii is incubated with aniline before the addition of glutamate, the decarboxylase activity progressively de- original activity was lost during this treatment, but once dried the enzyme was stable. A specimen kept in a desiccator for over a year showed no appreciable loss. For use a $10 \%$ suspension of the dry ground powder in water was made.

Guinea pig liver. Liver asparaginase was found to be associated mainly with the insoluble particles. On homogenizing liver with water or $0.9 \% \mathrm{NaCl}$ solution and centrifugation, the major part of the asparaginase activity remained in the sediment. A stable preparation free from interfering substances, which remained active for over a year, was 


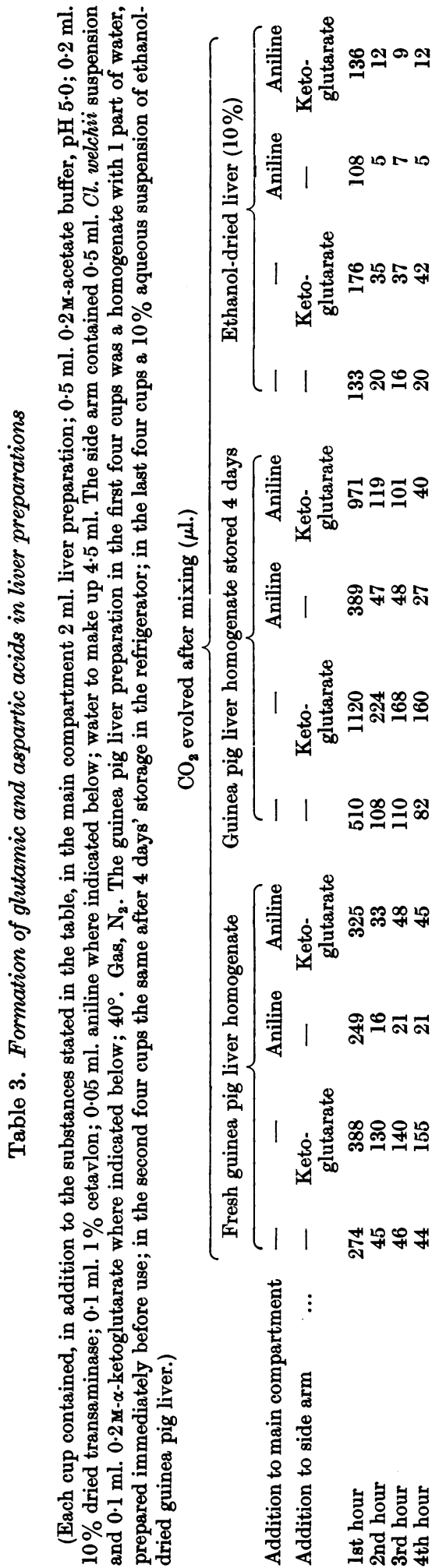

made as follows: Finely minced liver (cooled to $0^{\circ}$ ) was mixed with 2 vol. of ice-cold ethanol. The mixture was thoroughly stirred, centrifuged and the sediment was resuspended in 2 vol. ice-cold $50 \%(v / v)$ ethanol. The sediment was again centrifuged and then dried in a desiccator. About $50 \%$ of the original activity disappeared during the ethanol treatment. A $12 \%(w / v)$ suspension of the dry ground powder in water was used.

Fresh liver homogenates are not suitable for use in asparagine determinations because the proteolytic enzymes of liver tissue gradually release glutamic and aspartic acids from the tissue proteins. This results in a large blank value, i.e. evolution of $\mathrm{CO}_{2}$ in the absence of aspartic and asparagine in the unknown solution, a complication which does not arise when ethanol-treated liver is used. As may be seen from Table 3 fresh liver homogenates continuously evolve $\mathrm{CO}_{2}$ at $\mathrm{pH} 5.0$ in the presence of glutamic decarboxylase and the rate of $\mathrm{CO}_{2}$ evolution is increased by the addition of $\alpha$-ketoglutarate, indicating that both glutamic and aspartic acids continuously arise. A large proportion of the gas evolution during the first hour was caused by the decomposition of free glutamic and aspartic acids present in the liver preparations at the start, whilst the fairly constant rate of $\mathrm{CO}_{2}$ production during the next $3 \mathrm{hr}$. was due to the formation of the dicarboxylic amino-acids by proteolysis. In the freshly prepared guinea pig-liver homogenate $\mathrm{CO}_{2}$ evolution was slower than in the homogenate which had been stored for 4 days, presumably because the protein had been partially hydrolysed during storage (as indicated by the higher figures for $\mathrm{CO}_{2}$ evolution in the first hour) and because the free amino-acids arise more readily in the later stages of hydrolysis. Addition of aniline inhibited the production of both glutamic and aspartic acids in homogenates and ethanol treatment reduced it further. Ethanol treatment and addition of aniline together (last column of Table 3) reduced the generation of the amino-acids in the system used for the determination of aspartic acid and asparagine to negligible proportions (considering that the quantities of liver preparation used in the analytical test are one-quarter of that used in the experiment recorded in Table 3).

Quantity of enzyme preparation required. Sufficient quantities are, for each manometer vessel, $0.5 \mathrm{ml}$. of dialysed guinea pig serum, or of the $10 \%$ dried serum preparation, or of a $12 \%$ dried liver preparation. These quantities are of approximately equal activity. If the volume of the fluid in the manometer is to be kept low, the suspensions may be replaced by a corresponding amount of the dry powder.

\section{PROCEDURES}

Reagents. (a) Acetate buffer $0.2 \mathrm{M}, \mathrm{pH} 5.0 \quad$ (18.1 g. $\mathrm{NaC}_{2} \mathrm{H}_{3} \mathrm{O}_{2} \cdot 3 \mathrm{H}_{2} \mathrm{O}$ and 4.0 g. $\mathrm{CH}_{3} \mathrm{COOH}$ in 1 l.). (b) $\alpha$-Ketoglutarate, $0 \cdot 2 \mathrm{M}$ solution, prepared in small quantities from the acid and $\mathrm{m}-\mathrm{Na}_{2} \mathrm{CO}_{3}$ and stored in the refrigerator. For the preparation of $\alpha$-ketoglutaric acid see Friedman \& Kosower (1946). (c) Transaminase solution (fresh heart-muscle extract or $10 \%$ of dried preparation in $0.5 \% \mathrm{NaCl}$ ). (d) Suspension of Cl. welchii in acetate buffer, as described on p. 606 . (e) Aniline A.R., recently redistilled. (f) Cetyltrimethylammonium bromide ('cetavlon'), $2 \%$ in water. (g) Asparaginase preparation as described on p. 608. (h) L-Aspartate $0.2 \mathrm{M}$ or DL-aspartate $0.4 \mathrm{M}$, prepared in small quantities from the amino-acids and $\mathrm{M}-\mathrm{Na}_{2} \mathrm{CO}_{3}$ and stored in the refrigerator.

Determination of aspartic acid. Conical manometer cups with side arm and centre well are required. The side arm 
contains $0.2 \mathrm{ml}$. of $(a), 0.1 \mathrm{ml}$. of $(b), 0.2 \mathrm{ml}$. of $(c), 0.1 \mathrm{ml}$. of $(d)$ and $0.05 \mathrm{ml}$. of $(e)$; the main compartment $0.5 \mathrm{ml}$. of $(d)$, $0.1 \mathrm{ml}$. of $(f)$ and $3 \mathrm{ml}$. of unknown solution, the $\mathrm{pH}$ of which is adjusted to approx. 5 with $\mathrm{HCl}$ or $\mathrm{NaOH}$. The centre well contains a stick of yellow $P$ and the gas space $\mathrm{N}_{2}$; temperature $40^{\circ}$. A control cup contrins the same solutions except for the ketoglutarate solution in the side arm, which is replaced by the same volume of water. The manometers are shaken at $40^{\circ}$ until equilibrium is reached. The contents of the side arm are then emptied into the main compartment, and shaking is continued until the gas evolution ceases. The pressure changes in the control usually do not exceed 5-8 mm.

Since $1 \mathrm{~mol}$. of aspartic acid yields $2 \mathrm{~mol}$. of $\mathrm{CO}_{2}, 448 \mu \mathrm{l}$. $\mathrm{CO}_{2}$ correspond to $1.33 \mathrm{mg}$. aspartic acid.

Determination of asparagine plus aspartic acid. The conditions are the same as for the determination of aspartic acid except that $0.5 \mathrm{ml}$. of asparaginase preparation is added to the main compartment.

Determination of $\alpha$-ketoglutaric acid. The conditions are the same except that the $\alpha$-ketoglutarate solution in the side arm is replaced by $0.1 \mathrm{ml}$. of $\mathrm{L}$-aspartate solution or $0.2 \mathrm{ml}$. of DL-aspartate.

Shortened procedures. As already mentioned, omission of glutamic decarboxylase halves the yield of $\mathrm{CO}_{2}$. Except for the omission of the suspension of $\mathrm{Cl}$. welchii and the cetavlon solution the procedures for the determination of aspartic acid, asparagine and $\alpha$-ketoglutaric acid are the same.

Comment. Cetyltrimethylammonium bromide is added because it accelerates the decomposition of glutamine (Krebs, 1948; Hughes, 1949), which with the full procedure must necessarily take place in the unknown solution before the contents of the side arm and main compartment are mixed. If no glutamine is present, or if the shortened procedure is used, the detergent may be omitted.

Anaerobic conditions are used to exclude interference from the absorption of $\mathrm{O}_{2}$ which may occur with some biological materials. Air may be used in the gas space when it is known that $\mathrm{O}_{2}$ is not absorbed.

The quantities of $\alpha$-ketoglutarate and L-aspartate recommended are sufficient for the determination of equivalent amounts $\left(2 \times 10^{-5} \mathrm{~mol}\right.$.) of L-aspartate or $\alpha$-ketoglutarate respectively. The quantity of the unknown solution analysed must be so adjusted as to contain no more than $2 \times 10^{-5} \mathrm{~mol}$.

In the full procedure suggested, preformed glutamic acid in all solutions and preformed aspartic acid in the transaminase preparation are decomposed before the analysis of the unknown solution begins.

\section{Recovery experiments}

The aspartic acid used was a recrystallized specimen of the DL-compound supplied by Roche Products Ltd., the Lasparagine was the monohydrate and the $\alpha$-ketoglutaric acid (m.p. $113^{\circ}$ ) was prepared in the laboratory.

Full procedure. Representative data showing the recovery of aspartic acid, asparagine and $\alpha$-ketoglutaric acid from pure solutions are shown in Table 4. It will be seen with the lower concentrations of aspartic acid and asparagine (equivalent to $100 \mu \mathrm{l} . \mathrm{CO}_{2}$ and less) recovery was complete within the expected limits of error $( \pm 4 \%)$, but with higher concentrations the recovery was consistently a few per cent below the expected value. The consistency suggests that the small deficit results from a systematic shortcoming of the procedure, perhaps due to a side reaction of oxaloacetate, such as reduction to malate. As the deficit is very small it may be neglected in most cases. Recovery of $\alpha$-ketoglutarate was quantitative.

When aspartic acid was added to casein hydrolysate and to $\mathrm{HCl}$ extracts of animal tissues prepared as described below, recovery was the same as in pure solutions. This also applies to mixtures of $\mathrm{L}$-aspartate, $\alpha$-ketoglutarate and L-glutamate, provided that they did not contain transaminase. If present, transaminase may be inactivated by placing the solution for $10 \mathrm{~min}$. in boiling water.

Table 4. Recovery of L-aspartic acid, L-asparagine and $\alpha$-ketoglutaric acid from pure solutions

$$
\text { ('Full procedure.') }
$$

\begin{tabular}{lcc} 
& \multicolumn{2}{c}{$\mathrm{CO}_{2}$ evolved $(\mu \mathrm{l})}$. \\
\cline { 2 - 3 } Substance tested & Expected & Found \\
Aspartic acid & 45 & 47 \\
& 90 & 89 \\
& 189 & 180 \\
Asparagine & 448 & 436 \\
& $22 \cdot 4$ & 23 \\
& $44 \cdot 8$ & 43 \\
$\alpha$-Ketoglutaric acid & $89 \cdot 6$ & 88 \\
& 189 & 177 \\
& 448 & 439 \\
& 112 & 111 \\
& 224 & 222 \\
& 448 & 453
\end{tabular}

Shortened procedure. Recovery data are shown in Table 5. They are no less satisfactory than those obtained with the full procedure.

Table 5. Recovery of L-aspartic acid, L-asparagine and $\alpha$-ketoglutaric acid from pure solutions

('Shortened procedure.')

\begin{tabular}{lcc} 
& \multicolumn{2}{c}{$\mathrm{CO}_{2}$ evolved $(\mu \mathrm{l})}$. \\
\cline { 2 - 3 } Substance added & Expected & Found \\
DL-Aspartic acid & 28 & 30 \\
& 56 & 53 \\
& 112 & 112 \\
L-Asparagine & 224 & 228 \\
& 28 & 30 \\
$\alpha$-Ketoglutaric acid & 56 & 58 \\
& 112 & 116 \\
& 224 & 217 \\
& 28 & 27 \\
& 56 & 56 \\
& 112 & 110 \\
& 224 & 215
\end{tabular}

\section{APPLICATIONS}

L-Aspartic acid content of casein. Casein ('light white soluble', British Drug Houses Ltd., batch 406673/480824) (20.00 g.), containing 6.0\% moisture (determined by drying at $105^{\circ}$ ) and $4.5 \%$ ash (determined by incinerating at $500-550^{\circ}$ ), was mixed with $200 \mathrm{ml}$. of $6 \mathrm{~N}$-hydrochloric acid and heated in an oil bath at $120^{\circ}$ for $20 \mathrm{hr}$. The hydrolysate was diluted to $250 \mathrm{ml}$. in a measuring flask and 
a sample was diluted ten times with sufficient sodium hydroxide to bring the $\mathrm{pH}$ to about 5. This dilute solution $(1 \mathrm{ml}$.) yielded $235 \mu \mathrm{l}$. carbon dioxide from glutamic acid on addition of $\mathrm{Cl}$. welchii. In the aspartic acid determination (full procedure) $2 \mathrm{ml}$. yielded $310 \mu \mathrm{l}$. carbon dioxide. The L-glutamic acid content was thus $21.65 \mathrm{~g}$., the $\mathrm{L}$-aspartic acid content $6.25 \mathrm{~g} . / 100 \mathrm{~g}$. of dry and ash-free casein. Bailey, Chibnall, Rees \& Williams (1943) reported $22.00 \%$ glutamic acid and 6.68\% aspartic acid (cf. also Gordon, Semmett, Cable \& Morris, 1949).

Interconversion of $\mathrm{L}$-glutamate and $\mathrm{L}$-aspartate in rat-liver homogenates. This question arose in connexion with the study of the mechanism of transamination (Krebs \& Eggleston, 1948; Ratner \& Pappas, 1949). The hypothesis of Ratner \& Pappas postulates a formation of aspartate from glutamate in rat-liver homogenates and the following experiment shows that this occurs. Rat liver was homogenized with 15 parts of phosphate saline with additional magnesium chloride (see Krebs \& Eggleston, 1948). After addition of further saline or substrate solutions the final concentration of liver tissue was $5 \%$. The additional substrates included adenosinetriphosphate $(0.002 \mathrm{M}$ final concentration) in each case. Oxygen uptake and changes in the concentrations of glutamate and aspartate were measured (full procedure). The data in Table 6 refer to $4 \mathrm{ml}$. of homogenate.

It will be seen that about half of the glutamate removed appeared as aspartate. The accumulation of aspartate is probably due to the fact that its oxidative removal is relatively slow, especially in the second 30 min. of incubation. The extra oxygen uptake on addition of aspartate is very much smaller than that caused by the addition of glutamate. Aspartate is also converted into glutamate, but only about one-seventh of the aspartate removed is rerecovered as glutamate. This is not surprising in view of the rapid oxidation of glutamate under the test conditions.

Aspartic acid, asparagine and $\alpha$-ketoglutaric acid in animal tissues. Animal tissues were removed from the body as soon as possible after death, frozen in solid carbon dioxide and kept in the frozen state until analysed. For analysis the material was allowed to thaw ; immediately after thawing $20 \mathrm{~g}$. of tissue were homogenized in a Waring blender with $40 \mathrm{ml}$. of $0.5 \mathrm{~N}$-hydrochloric acid. The homogenate was centrifuged and 2 or $3 \mathrm{ml}$. of the supernatant were used for each analysis (full procedure). Sufficient $2 \mathrm{~N}$-sodium hydroxide (usually $0.15 \mathrm{ml} . / \mathrm{ml}$. extract) was added to the manometer cups to reduce the acidity of the tissue extract to $\mathrm{pH} 5 \cdot 0$. Data obtained with this technique are shown in Table 7. The tissues examined all contained some $\alpha$-ketoglutaric acid, the quantities being of the order of $10^{-6} \mathrm{~mol} . / \mathrm{g}$. (15 mg./100 g.). The amounts of aspartic acid and asparagine were below the range of the method in pigeon-breast muscle and guinea pig liver, but were measurable in several other tissues. Compared with the quantities of glutamic acid and glutamine present in animal tissues (Krebs, Eggleston \& Hems, 1949) those of aspartic acid and asparagine were very small. The ratio glutamic acid plus glutamine : aspartic acid plus asparagine is about 30 for sheep kidney cortex, 12 for sheep spleen, 30 for sheep brain, 100 for pigeon-breast muscle. Free asparagine was detectable in spleen, kidney and liver of sheep. Its presence in animal tissues does not appear to have been recorded before.

Table 6. Interconversion of $\mathrm{L}$-glutamate and $\mathrm{L}$-aspartate in rat-liver homogenates

(Temp. $40^{\circ}$. Gas phase, $\mathrm{O}_{2}$. For other experimental details see text.)

\begin{tabular}{|c|c|c|c|c|c|c|}
\hline \multirow[b]{3}{*}{ Substrates added to $4 \mathrm{ml}$. } & \multicolumn{6}{|c|}{ Changes observed ( $\mu$ l.) } \\
\hline & \multicolumn{2}{|c|}{$\mathrm{O}_{2}$} & \multicolumn{2}{|c|}{ Glutamate } & \multicolumn{2}{|c|}{ Aspartate } \\
\hline & $30 \mathrm{~min}$. & $60 \mathrm{~min}$. & $30 \mathrm{~min}$. & $60 \mathrm{~min}$. & $30 \mathrm{~min}$. & $60 \mathrm{~min}$. \\
\hline $\begin{array}{l}\text { None } \\
\text { L-Glutamate }(846 \mu \mathrm{l} .) \\
\text { L-Aspartate }(904 \mu \mathrm{l} \text {. }\end{array}$ & $\begin{array}{l}-350 \\
-625 \\
-395\end{array}$ & $\begin{array}{r}-460 \\
-1507 \\
-565\end{array}$ & $\begin{array}{r}- \\
-237 \\
+51\end{array}$ & $\begin{array}{r}+4 \\
-482 \\
+59\end{array}$ & $\begin{array}{l}\overline{130} \\
+\mathbf{3 6 7}\end{array}$ & $\begin{array}{r}+5 \\
+201 \\
-375\end{array}$ \\
\hline
\end{tabular}

Table 7. Aspartic acid, asparagine and $\alpha$-ketoglutaric acid in animal tissues immediately after death

(For procedure see text.)

\begin{tabular}{|c|c|c|c|}
\hline \multirow[b]{2}{*}{ Tissue } & \multicolumn{3}{|c|}{$\left(10^{-6} \mathrm{~g} . \mathrm{mol} \cdot / \mathrm{g}\right.$. tissue $)$} \\
\hline & $\begin{array}{l}\text { Aspartic } \\
\text { acid }\end{array}$ & Asparagine & $\begin{array}{c}\alpha \text {-Ketoglutaric } \\
\text { acid }\end{array}$ \\
\hline Kidney cortex, sheep & $0 \cdot 23$ & 0.06 & $1 \cdot 7$ \\
\hline Spleen, sheep & 0.97 & $0 \cdot 17$ & $0 \cdot 4$ \\
\hline Brain (whole), sheep & 0.44 & $<0.05$ & 0.73 \\
\hline Liver, sheep & $0 \cdot 20$ & 0.15 & $2 \cdot 1$ \\
\hline Cardiac muscle, sheep & $0 \cdot 15$ & 0.05 & 0.05 \\
\hline Striated muscle, pigeon & $<0.05$ & $<0.05$ & $1 \cdot 0$ \\
\hline Liver, guinea pig & $<0.05$ & $<0.05$ & 0.3 \\
\hline
\end{tabular}


Very different results were obtained when the tissues were not frozen immediately, or if after freezing they were stored in the refrigerator at about $+2^{\circ}$ or if less acid solutions were used in extracting the tissues (see Table 8). Unless enzymic activities are suppressed after killing, the concentrations of aspartic acid and asparagine increase and that of $\alpha$ ketoglutaric acid falls, the former being due to protein decomposition, the latter to transamination of ketoglutaric acid with the newly formed aspartic acid. Ten- to a hundred-fold increases in the amounts of aspartic acid and asparagine were recorded. Asparagine appeared especially in extracts made with $0.1 \mathrm{~N}$-hydrochloric acid or $0.12 \mathrm{~N}$-metaphosphoric acid. The dilute acids produce a $\mathrm{pH}$ at which the proteolytic enzymes are relatively more active than asparaginase.

Aspartic acid, asparagine, glutamic acid and glutamine in germinating peas. Seedlings of the legume family are known to produce glutamine and asparagine, especially when growing in the absence of light (Chibnall, 1939; Vickery, Pucher \& Deuber, 1942; Vickery \& Pucher, 1943). Peas (Carter's 'Early Superb') were grown in sawdust at $25^{\circ}$ in a dark room. One group was kept moist with tap water, the other with a solution of $0.05 \%$ ammonium bicarbonate in tap water. For analysis the whole seedlings were ground in the presence of sand with $0.5 \mathrm{~N}$-hydrochloric acid $(5 \mathrm{ml} . / \mathrm{g}$. of tissue). Of the resulting suspension $2 \mathrm{ml}$. were used for the determination of glutamic acid and glutamine according to Krebs (1948) and 0.5-2 ml. each for the determination of aspartic acid and asparagine (full procedure). Sufficient sodium hydroxide was added to bring the $\mathrm{pH}$ of the suspension to about 5 before the acetate buffer was added. Results are shown in Table 9. At the start of germination a little glutamine, but no glutamic acid, aspartic acid or asparagine, was present. After 10 days all four compounds were found with asparagine prevailing. Subsequently glutamic acid, glutamine and aspartic acid fluctuated only little, but the concentration of

Table 8. Aspartic acid, asparagine and $\alpha$-ketoglutaric acid in animal tissues subjected to various treatments

(Unless otherwise stated the tissues were extracted with 2 vol. of $0.5 \mathrm{~N}-\mathrm{HCl}$.)

Tissue

Liver, guinea pig

Kidney cortex, sheep

Kidney cortex, sheep

Spleen, sheep

Spleen, sheep

Liver, sheep

Brain (whole), sheep

Striated muscle, pigeon
Treatment

Frozen in $\mathrm{CO}_{2}$, thawed and stored at $20^{\circ}$ for $40 \mathrm{hr}$.

Frozen in $\mathrm{CO}_{2}$, homogenized with 2 vol. $0 \cdot 1 \mathrm{~N}-\mathrm{HCl}$; homogenate left $18 \mathrm{hr}$. at $20^{\circ}$

Cooled in ice water, homogenized with 2 vol. 0.12N-metaphosphoric acid

Frozen in $\mathrm{CO}_{2}$, thawed and stored at $2^{\circ}$ for $48 \mathrm{hr}$.

Cooled in ice water, homogenized with 2 vol. $0 \cdot 12 \mathrm{~N}$-metaphosphoric acid

Frozen in $\mathrm{CO}_{2}$, thawed and stored at $2^{\circ}$ for $48 \mathrm{hr}$.

Frozen in $\mathrm{CO}_{2}$, thawed and stored at $2^{\circ}$ for $48 \mathrm{hr}$.

Frozen in $\mathrm{CO}_{2}$, thawed and stored at $20^{\circ}$ or $48 \mathrm{hr}$. $\left(10^{-6} \mathrm{~g} \cdot \mathrm{mol} . \mathrm{g}\right.$. tissue)

$\begin{array}{ccc}\begin{array}{c}\text { Aspartic } \\ \text { acid } \\ 20.6\end{array} & \begin{array}{c}\text { Asparagine } \\ 13.6\end{array} & \begin{array}{c}\alpha \text {-Ketoglutaric } \\ \text { acid }\end{array} \\ 16.2 & 0 \\ 1.4 & 1.1 & 0 \\ 2.1 & 2.5 & 0 \\ 7.0 & 4.3 & 0.3 \\ 2.7 & 0.3 & 0 \\ 2.8 & 0 & 0 \\ 3.3 & 0.4 & 0.3\end{array}$

Table 9. Aspartic and glutamic acids and their amides in etiolated pea seedlings

(For growth conditions see text; the initial value was obtained from material soaked in water for $24 \mathrm{hr}$. at $20^{\circ}$.)

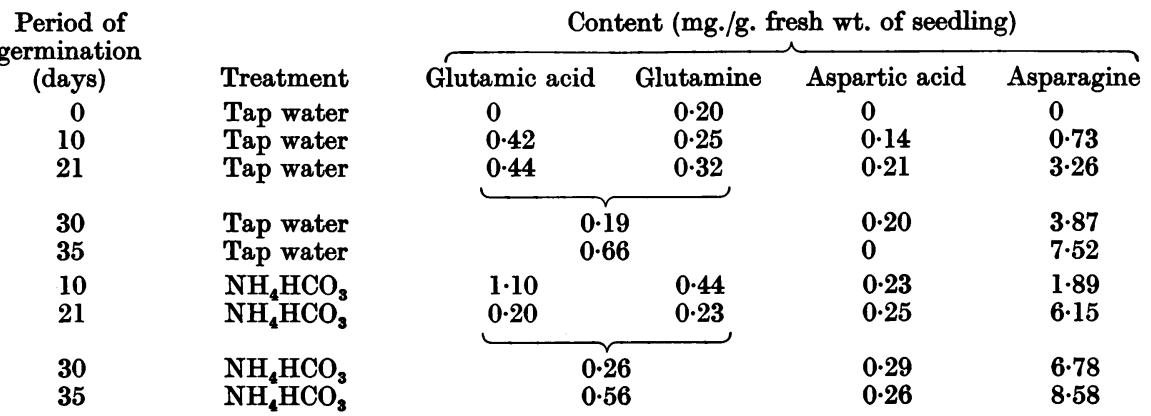


asparagine rose. Addition of ammonium salts increased the amount of asparagine, and in the early stages also those of glutamic acid. The highest concentration of asparagine (expressed as anhydrous product) observed was $8.58 \%$ of the wet weight of pea seedlings. The water content of this sample was $94.0 \%$. Thus $14 \cdot 3 \%$ of the dry matter of the seedling consisted of anhydrous asparagine. Vickery et al. (1942) and Vickery \& Pucher (1943) found for Lupinus albus a maximum asparagine content of $\mathbf{2 5 . 4} \%$ of the dry matter, for L. angustifolius, $14.5 \%$ and for Vicia atropurpurea, $8 \cdot 1 \%$. The data obtained on peas suggests that they may be a satisfactory source for the preparation of asparagine.

\section{DISCUSSION}

The specificity of the methods described is governed by the specificity of the enzyme preparations used. With the exception of cysteic acid which is usually absent, aspartic acid is the only amino-acid which reacts with ketoglutarate under the conditions of the test, and ketoglutaric acid the only $\alpha$-ketonic acid which reacts with aspartic acid. The specificity of the methods is therefore very high. A complication may arise if the material to be examined contains proteins together with proteolytic enzymes. In this case aspartic acid may be formed from protein during the determination, and the result represents free plus part of the combined aspartic acid (see Schurr, Thompson, Henderson \& Elvehjem, 1950). Errors of this kind can be prevented by heat inactivation of the proteolytic enzymes in the unknown solution.

A number of micromethods for the determination of L-aspartic acid have been elaborated in recent years, using the following principles: microbiological assay with Leuconostoc mesenterioides P-60 (Hac \& Snell, 1945); treatment with nitrous acid and polarimetric determination of the malic acid formed (Roberts, 1947); treatment with methyl sulphate and alkali, reduction of the fumaric and maleic acids formed to succinic acid and manometric determination of the latter (Braunstein, Nemchinskaya \& Vilenkina, 1947); treatment with methyl sulphate and polarographic determination of the unsaturated acids formed (Warshowsky \& Rice, 1948); conversion into acetaldehyde and colorimetric determination of the latter (Fromageot \& Colas, 1949); decomposition with bacterial aspartase and determination of the ammonia formed (Virtanen \& Louhivuori, 1947, 1948); bacterial decarboxylation by an organism, provisionally called Pseudo mycobacterium (which is not generally available) and manometric determination of the carbon dioxide formed (Mardashev \& Gladkova, 1948).

The method for the determination of aspartic acid described in this paper compares favourably with those quoted in respect to accuracy or specificity or sensitivity or convenience, with the possible exception of the method of Mardashev \& Gladkova (1948) which could not be tested.

An alternative method for the determination of $\alpha$ ketoglutarate is based on the isolation of the 2:4dinitrophenylhydrazone, the oxidation of the latter to succinate with acid permanganate and the manometric determination of the succinate (Krebs, 1938). The present method is more rapid, and in terms of gas evolution its sensitivity is four times greater.

The principle used for the determination of aspartic acid may also be applicable to the determination of alanine or other amino-acids which transaminate with $\alpha$-ketoglutarate. Sufficiently active preparations of the necessary enzymes are, however, not yet available.

\section{SUMMARY}

1. Manometric methods for the determination of $\mathbf{L}$-aspartic acid, L-asparagine and $\alpha$-ketoglutaric acid, based on the use of aspartic-glutamic transaminase, oxaloacetic decarboxylase and glutamic decarboxylase, are described.

2. I-Aspartic acid is determined by the addition to the solution to be examined of aspartic-glutamictransaminase, oxaloacetic decarboxylase (plus aniline), glutamic decarboxylase and an excess of $\alpha$ ketoglutarate. Transamination followed by the decarboxylation of the glutamic and oxaloacetic acids formed leads to the formation of two molecules of carbon dioxide per molecule of aspartic acid. Glutamic decarboxylase may be omitted; in this case one molecule of carbon dioxide is formed per molecule of aspartic acid.

3. Asparagine behaves like aspartic acid if asparaginase is present.

4. $\alpha$-Ketoglutarate is determined on the same principle by adding to the solution to be examined the above mixture of enzymes and an excess of aspartic acid.

5. The methods have been applied to the analysis of casein, of animal tissues, homogenates from animal tissues and plant material.

6. A rapid conversion of glutamic acid into aspartic acid is shown to occur in respiring liver homogenates.

7. Data on the changes in the content of aspartic acid and glutamic acid and their amides in growing etiolated pea seedlings are given.

8. Data are also given on the concentrations of aspartic acid, asparagine and $\alpha$-ketoglutaric acid in animal tissues and on the changes in these concentrations which occur soon after death as a result of autolysis.

The author wishes to thank Mr D. E. Hughes for data on the properties of glutamic decarboxylase preparations and Mr R. Hems and Miss E. Ellis for technical assistance. 


\title{
REFERENCES
}

Bailey, K., Chibnall, A. C., Rees, M. W. \& Williams, E. F. (1943). Biochem. J. 37, 360.

Boulanger, P. \& Osteux, R. (1949). Bull. Soc. Chim. biol., Paris, 31, 1290.

Braunstein, A. E. (1947). Advanc. prot. Chem. 3, 1.

Braunstein, A. E., Nemchinskaya, V. L. \& Vilenkina, G. J. (1947). Biochim. Biophys. Acta, 1, 281.

Bychov, J. M. (1939). Biokhimiya, 4, 189.

Chibnall, A. C. (1939). Protein Metabolism in the Plant. New Haven: Yale University Press.

Clementi, A. (1922). Arch. int. Physiol. 19, 369.

Clementi, A. \& Prampolini, P. (1929). Arch. Sci. biol., Napoli, 13, 443.

Cohen, P. P. (1940). J. biol. Chem. 136, 565.

Friedman, L. \& Kosower, E. (1946). Organic Synth. 26, 42.

Fromageot, C. \& Colas, R. (1949). Biochim. Biophys. Acta, 3, 417.

Fürth, O. von \& Friedmann, M. (1910). Biochem. Z. 26, 435.

Gale, E. F. (1945). Biochem. J. 39, 46.

Gale, E. F. (1947). Biochem. J. 41, vii.

Geddes, W. F. \& Hunter, A. (1928). J. biol. Chem. 77, 197.

Gordon, W. G., Semmett, W. F., Cable, R. S. \& Morris, M. (1949). J. Amer. chem. Soc. 71, 3293.

Green, D. E., Leloir, L. F. \& Nocito, V. (1945). J. biol. Chem. 161, 559.

Hac, L. R. \& Snell, E. E. (1945). J. biol. Chem. 159, 291.

Hiwatasi, D. (1941). Tohoku J. exp. Med. 41, 298.

Hughes, D. E. (1949). Biochem. J. 45, 325.
Krebs, H. A. (1938). Biochem. J. 32, 108.

Krebs, H. A. (1948). Biochem. J. 43, 51.

Krebs, H. A. \& Eggleston, L. V. (1948). Biochim. Biophys. Acta, 2, 319.

Krebs, H. A., Eggleston, L. V. \& Hems, R. (1949). Biochem. J. 44, 159.

Lang, S. (1904). Beitr. chem. Physiol. Path. 5, 321.

Lepper, E. \& Martin, C. J. (1929). Brit. J. exp. Path. 10, 327.

McIlwain, H. \& Hughes, D. E. (1944). Biochem. J. 38, 187.

Mardashev, S. R. \& Gladkova, V. N. (1948). Biokhimiya, 13, 315.

O'Kane, D. E. \& Gunsalus, I. C. (1947). J. biol. Chem. 170, 425.

Ratner, S. \& Pappas, A. (1949). J. biol. Chem. 179, 1183 , 1199.

Roberts, I. S. (1947). Exp. Med. Surg. 5, 251.

Schurr, P. E., Thompson, H. T., Henderson, L. M. \& Elvehjem, C. A. (1950). J. biol. Chem. 182, 29.

Suzuki, Y. (1936). J. Biochem., Tokyo, 23, 57.

Taylor, E. S. \& Gale, E. F. (1945). Biochem. J. 39, 52.

Vickery, H. B. \& Pucher, G. W. (1943). J. biol. Chem. 150, 197.

Vickery, H. B., Pucher, G. W. \& Deuber, C. G. (1942). J.biol. Chem. 145, 45.

Virtanen, A. I. \& Louhivuori, A. (1947). Acta chem. scand. 1, 799.

Virtanen, A. I. \& Louhivuori, A. (1948). Arch. Biochem. 16, 151.

Warshowsky, B. \& Rice, M. W. (1948). Anal. Chem. 20, 341.

\section{The Isolation from Normal Tobacco Leaves of Nucleoprotein with some Similarity to Plant Viruses}

\author{
By N. W. PIRIE \\ Rothamsted Experimental Station, Harpenden, Hertfordshire
}

(Received 28 June 1950)

Thirty years ago various lines of evidence defined the limits of size within which the viruses fell, and it became obvious that viruses were larger than other soluble materials that had by that time been studied biochemically. It was generally assumed that they were largely protein, and it was therefore probable that they would be dense enough to be separable by centrifugation; this was achieved with tobacco mosaic virus by Bechold \& Schlesinger (1933). Infective material has been sedimented from extracts of diverse origin in many different laboratories, and the products so obtained are generally spoken of as if they consist largely or even exclusively of virus. This usage depends on the underlying assumption that particles with physical properties similar to those of viruses are rare in uninfected tissues. Claude (1940) showed that the assumption was unfounded and, using the same techniques on normal tissue that were being used to make preparations of Rous sarcoma virus from tumour tissue, he prepared virus-like material from a range of tissues. His investigations laid the foundations of our knowledge of macromolecular tissue components. The need for adequate controls is so well recognized in biochemistry that it seems odd at first sight that preparations from uninfected tissues should not have been made earlier and more extensively. Much of our knowledge of viruses has, however, come from work that was not primarily concerned with their biochemistry, and it is often by no means easy to see which normal tissue would be most suitable for use as a control, and in what nutritional state it should be. Whatever the reason, no work on plant material has so far been published that is at all comparable in 